\title{
Demand for Public Education: Evidence from a Rural School District
}

\author{
Anthony Stair*, Terance J. Rephann ${ }^{\star *} \#$, and Matt Heberling ${ }^{\star \star *}$ \\ *Associate Professor and Chair \\ Department of Economics \\ Frostburg State University \\ Frostburg, MD 21532 \\ astair@frostburg.edu \\ ${ }^{* *}$ Director of Institutional Research \\ Allegany College of Maryland \\ 12401 Willowbrook Road, SE \\ Cumberland, MD 21502 \\ trephann@allegany.edu \\ ${ }^{* * *}$ Economist \\ US Environmental Protection Agency \\ Office of Research and Development \\ National Center for Environmental Assessment (MS 190) \\ Cincinnati, $\mathrm{OH} 45268$ \\ heberling.matt@epa.gov
}

\# Author for correspondence

Keywords: rural, education, demand, contingent valuation

\begin{abstract}
There has been much debate in recent years about the quality of local public education in the United States. Much of this discussion has centered around the apparent underperformance of children in basic areas like reading, math, and English as reflected by low scores on standardized achievement exams relative to their international peers and the appropriate level of educational spending. This study examines the question of how much households are willing to pay for improvements in the quality of local public education in two areas of a rural school district in Pennsylvania. The study uses the contingent valuation technique to obtain micro-data by personal interview on demand for improved public school quality.

Estimates of willingness to pay are computed and logit/Tobit analyses are used to determine what household characteristics are associated with household willingness to pay. The results of this analysis indicate that the majority of respondents do value improved public school quality and that residents would pay up to approximately twenty-five percent of current educational budgets for a ten percent improvement in school quality as measured by achievement test performance. However, lower income households and those with fewer connections to the local public school are less likely to be supportive of increased expenditures.
\end{abstract}

The views expressed in the paper are those of the authors alone

http://www.equotient.net

Published in Economics of Education Review 25, 5: 521-531. 


\subsection{Introduction}

There has been much debate in recent years about the quality of local public education in the United States. Much of this discussion has centered around the apparent underperformance of children in basic areas like reading, math, and English as reflected by low scores on standardized achievement exams relative to their international peers (Heckman 2000). Inevitably the discussion converges on the issue of what the appropriate spending levels for public education should be. Judging from the number of highly publicized local property tax revolts that have occurred, one might conclude that the U.S. public has already reached a limit with respect to spending on public education. Would households be willing to pay more for improved public education? What household characteristics influence willingness to pay?

This study addresses these questions by determining household willingness to pay for improvements in the quality of local public education in two areas of a rural school district located in Pennsylvania. Population willingness to pay for improvement in local public school is projected using sample data. An econometric analysis of households not willing to pay anything for improvements in local public education is conducted to determine whether zero bidders possess any unusual characteristics. Additional econometric analysis is completed to determine what household characteristics influence the magnitude of household willingness to pay for improvements in public school quality.

This study uses a different indicator of school quality than past studies concerned with the demand for public education. School quality in the local area is represented by school-wide achievement scores relative to the national average. Previous studies used expenditures per student to represent school quality. However, Hanushek (1986) found that generalized expenditures spent per student are not directly related to school quality. Moreover, expenditures per student are not commonly perceived as an output of the public education system.

The study uses the contingent valuation technique to obtain micro data by personal interview on demand for improved public school quality. Contingent valuation is a survey technique that allows the researcher to measure consumer welfare change from improvements in a non-market good. It differs from conventional survey techniques in that the researcher designs a hypothetical market involving a change in the level of provision for some non-market good. The value the respondent places on the improvement is contingent upon the researcher's description of the market; hence the name contingent valuation. Over the past decades contingent valuation has gained increasing acceptance. In 1979 the Water Resources Council listed contingent valuation as one of three methods recommended for project evaluation. In addition, there is a plethora of published research indicating that properly designed contingent valuation studies yield consistent results. In the past, contingent valuation has been used most commonly to value environmental commodities like air or water pollution. However, this technique may be used to value improvements in other non-market commodities, specifically public education (Mitchell and Caron 1989).

This paper is divided into six sections. The first section reviews the literature on the demand for public education. The next section discusses the contingent valuation method. The third describes data collection and implementation, including the selection of covariates used in multivariate econometric analysis. The fourth section discusses empirical results for an econometric analysis of households not willing to pay anything for improvements in local public education, and the results that describe what household characteristics influence the magnitude of household willingness to pay for improvements in public school quality. The last section contains summary and conclusions.

\subsection{Estimating demand for education}

The techniques used in estimating demand for public goods in general and public education in particular have evolved from median voter model estimations using aggregate data to survey-based research during the past three decades. The starting point is Barlow (1970) who addressed efficiency aspects of local school finance. His work provided the logic for the use of the median voter hypothesis in the evaluation of the demand for and efficiency in the provision of public education. Any program meeting approval from a public vote will be approved by the median voter. Therefore, those programs that are approved can be successfully explained by an analysis of one voter: the median voter. 
In a system of majority rule, public good quantity or quality increases would be approved up to the point where the median voter found that his marginal benefit was equal to the marginal cost incurred. Barlow assumed that the household demand for public education was a simple multiplicative function of income and the price of public education to the household. He solved this demand equation for price to determine the individual household's marginal benefit from the level of public education currently provided. Using residential property tax shares calculated from another study to represent the burden, Barlow calculated the current benefit to burden ratio of the median voter to be significantly different from one. He concluded that the amount of education provided through the residential property tax was below the efficient level. Barlow concluded that his analysis was oversimplified because his demand for education equation was oversimplified and that other variables might have been included in this equation like the number of children per household or religious affiliation.

Other attempts have been made to use the median voter model to examine public education. Akin and Youngday (1976) estimated efficiency levels of expenditure for 104 school districts in New York State using the median voter model. They found that most schools were operating below efficiency but some were above efficiency. Overspending on education was correlated with a larger nonresidential tax base. Lovell (1978) found that the median income and the median number of years of education completed by the voters had a significant positive effect on demand for expenditures per student.

Such studies assume that the median voter's characteristics are represented by median characteristics represented by census data. This is not always realistic because of sampling issues. Moreover, Cornes and Sandler $(1986,251)$ state that the median voter model assumes that public good provision is decided in unidimensional elections. But, most elections involve candidates who run on multidimensional platforms. In addition, studies using the median voter model with aggregate data are often plagued by empirical problems. Among these are specification bias, simultaneous equation bias, and multicollinearity. Because of these problems, estimation of demand for public schooling using micro data is more appropriate in some situations. Indeed, the use of microdata has been shown to have clear advantages as demonstrated by Akin and Lea (1982). They compared a median voter approach with aggregate data to a micro-data approach and found that the latter produced better results.

One form of microdata is survey data of referenda choices. Rubinfeld (1977) introduced the use of survey data in demand estimation for public schooling by using a follow-up survey of two separate Detroit area referenda. The yes/no vote in the election was examined by using a binary choice logit model. Micro-data from a Michigan voters survey conducted in 1980 have also been used. The Marshall school district in Michigan held a referendum in August 1979 to determine operating expenditures for the 1979-1980 school year. After the election, a mail survey was distributed which asked individuals to state how they voted or would have voted, and household characteristics. Lankford (1986) used information obtained from the survey to fit a multinomial probit random utility model to obtain information concerning the preferences mappings of the respondents. Estimates of citizen demand for public education were then inferred from these mappings. Using the same micro data set, Lankford (1986) analyzed efficiency in school spending. He found the sum of the marginal utilities to be less than the marginal costs and concluded that overspending had occurred for public education in Michigan. Bergstrom, Rubinfeld, and Shapiro (1982) estimated demand for public schooling utilizing similar micro data collected from numerous school districts in Michigan. Unlike Lankford, these authors directly estimated demand for public education and efficiency in the supply of public schooling. In their analysis they developed a model which eliminates the effects of Tiebout bias, a bias which occurred because people took into account their preferences for public goods when they choose where to live. ${ }^{1}$ When they corrected for Tiebout bias using instrumental variables, they found that results which initially suggested substantial under spending changed to substantial overspending.

Many articles involving empirical estimation of public spending for non-market goods have utilized micro data derived from a contingent valuation approach. However, public education has not been the subject of investigation. The next section takes a closer look at contingent valuation, its use in various fields, and its potential for application to the public education valuation problem. 


\subsection{The contingent valuation method}

Economists have spent much time observing how people obtain value from non-market goods. Understanding the sources of value helps in the development of ways to measure that value. There are two general methods in which these values are estimated: observing tradeoffs (revealed preference) or asking about tradeoffs (stated preference). One example of a revealed preference technique is the hedonic price method. Typically, this method examines the relationship among housing prices and the houses' characteristics. For example, a house has attributes such as size of the house, size of the yard, crime rate in neighborhood, environmental quality, and public education quality. A hedonic price function expresses the equilibrium price for a house as a function of its attributes. To estimate how a small change in public education affects the equilibrium house price, one would partially differentiate the hedonic price function (Hanley and Spash 1993). This method, however, needs changes that will affect the house price. If the change does not affect the price of a house, this technique will not work.

One specific stated preference technique, the contingent valuation method, measures the value of public goods directly. Surveys are developed for the purpose of eliciting economic values for nonmarket goods and services based on the description of a market or other means of payment (Bishop et al. 1995). Examples of these surveys have been administered through the mail, over the phone, in person, and more recently across the Internet (e.g., Thurston 2000). Contingent valuation measures a value by asking respondents' their willingness to pay for or willingness to accept (depending on the property rights) a change using a specified payment vehicle (e.g., a change in the electric bill or taxes). This vehicle needs to be realistic in order for the respondents to believe that the change will occur and that the money will be used as stated.

The contingent valuation method is a popular economic valuation technique. Many books are written about the technique such as Mitchell and Carson (1989) who provide the most thorough description of the method. According to Carson (2000), there are over 2000 papers and studies dealing with the topic. Most applications and studies have dealt with changes to the environment or human health. Relatively few studies have looked at other public goods besides environmental goods (e.g., see Carson et al. 1995; Chambers et al. 1996; Kawagoe and Fukunaga 2001).

Mitchell and Carson $(1989,295)$ describe contingent valuation as a "versatile tool for directly measuring a range of benefits for a range of goods consistent with economic theory." In terms of the applications, they are correct. For one reason, the contingent valuation method measures both use and non-use values. Use values are related to the direct consumption of a public good and non-use values (Mitchell and Carson 1989; Turner 1999; Carson 2000). Option value, a type of use value or sometimes a separate category, reflects the value in order to preserve the options to use the resource at some later time. Nonuse values, which are sometimes further decomposed into bequest and existence value, reflect the value of improving or preserving public goods households will never use. For example, parents' who have children using a public education institution may have a use value for that institution. If homeowners within a school district do not have children, they may have altruistic values for others' use or bequest values for future generations. No other technique would be able to capture these non-use values.

Much of the scrutiny on contingent valuation has been focused on the potential biases that may occur with poorly designed instruments (Mitchell and Carson 1989; Hanley and Spash 1993; Carson et al. 1996; Carson 2000; Tietenberg 2000). For example, if the hypothetical market makes responses different from truth, then the results will be affected by the hypothetical bias. Respondents may try to influence the outcome by under or overestimating their true bid, a type of strategic bias. If the payment vehicle causes the true value to be under or overestimated, then payment vehicle bias may affect the results. Although there are many potential biases, Carson $(2000,1417)$ states a contingent valuation study can be useful for decision making, and that "the spotlight placed upon contingent valuation has matured it; its theoretical foundations and limits to its uses are now better understood." Bishop et al. $(1995,629)$ echoes that by saying that the contingent valuation method "has received considerable acceptance in the United States as a tool for measuring values to be used in benefit-cost analysis." 


\subsection{Data and Implementation}

\subsection{Sampling technique}

This study deals with willingness to pay for improvement in public school quality within two separate but adjacent high school areas located in the Bedford School District in Pennsylvania: Bedford High School and Hyndman High School. The areas are $99.9 \%$ white and largely rural but the Bedford High area has approximately 5,405 households versus 1,099 in Hyndman.

A questionnaire (described in Stair (1993) was developed which asked respondents to describe various household attributes (e.g., household size, household income, occupations, employment location) and what they would be willing to pay for various types of school improvements. Since Hyndman High School area lagged behind Bedford High School area in student performance, the groups were queried differently. Respondents in Hyndman were asked the most they would be willing to pay for an improvement from the current $55^{\text {th }}$ percentile (relative to statewide school district scores) to the $65^{\text {th }}$ percentile in pupil achievement tests administered between grades 6 and 12. Bedford residents were presented with an improvement from their current level of $65^{\text {th }}$ percentile to the $75^{\text {th }}$ percentile.

The study sample of 231 households was constituted by choosing random households from district tax rolls. The sample was found to be similar in composition to Census data for these political districts. Of the 231 households contacted, interviews were obtained from 198 for a response ratio of $85.7 \%$. Protest bids and observations obtained from respondents who did not understand the questionnaire were excluded resulting in a total of 190 usable responses. The empirical analysis described below is based on these observations.

\subsection{Willingness to pay and its determinants}

In order to examine the role of household attributes in respondents' willingness to pay, three analyses are conducted. The first a straightforward calculation of the willingness to pay and its size when extrapolated to the entire district relative to current school expenditures. The second is a probit analysis of whether a person bids zero or positively for improvements in public school quality. The third is a Tobit analysis of household willingness to pay for marginal improvements in public school quality. Each regression draws on explanatory factors identified in the literature. The rationales for these factors and their empirical implementation in the models here (see table 4.1) are described below.

\section{Household income and income security}

Rubinfeld (1977), Akin and Youngday (1976), Bergstrom et al. (1982), and Lankford (1985) found that demand for increased expenditures per student varies directly with income. Following similar logic, demand for improvements in public school quality should also be heavily influenced by household income. Two measures of household income are used here, household income (INCTEN) and household income squared (INCTEN2). The squared term is used in the Tobit analysis only to capture the possibility that demand for increased public school quality increases at a decreasing rate with respect to household income. The sign of the income variable is expected to be positive while the sign of income squared is expected to be negative.

The level of income security of the primary income earner may affect willingness to pay. If the respondent feels that the primary income earner's income is at least somewhat secure he or she may be more willing to pay for school quality increases. Income security is represented by the perceived income security of the primary income earner (SWSEC) and is hypothesized to be positive.

\section{Occupation and education.}

The occupation and educational achievement levels of the members of the household may also affect household willingness to pay for increases in public school quality. Lankford (1986) shows that white-collar heads of household have a greater willingness to pay for increased school expenditures and Bergstrom et al (1982) find that education has a positive significant effect on demand for public school expenditures per student. Therefore, an indicator of whether a household member holds a white-collar position (OCCW) and variable representing the highest education level completed by a household member (HIGHED) are included. 


\section{Children}

Having children or grandchildren in the school system and household size may affect demand for education and respondents would have a use value for education. Rubinfeld (1977), Bergstrom et al. (1982), Akin and Lea (1982), Lankford (1985), and Miller (1996) found the presence of children currently in public school had a significant positive effect on demand for expenditures per student. Whereas previous studies focused on the entire educational system, grades $\mathrm{K}$ through twelve, this paper focuses only on improvements in grades six through twelve. Therefore, two dummy variables are introduced: one that represents households with children who would be directly impacted in grades six through twelve (GR6UD) and another one for households with children in grades k-5 (GRK5D) (whose children will eventually enter grades six through twelve; an option value). Both variables are hypothesized to have positive signs. Older households too may be concerned about their grandchildren. If the respondent has grandchildren currently attending the local public school, he or she should be willing to pay more for school quality increases than respondents who do not (Miller 1996). Therefore, a variable (GRANDPUB) for households having grandchildren enrolled is introduced.

\section{Household size and age}

Household size may have an independent effect. Previous studies have shown that the number of people currently in the household has an affect on demand for increased school expenditures. Lankford (1986) found this variable to be negative and significant. It may be serving as a proxy for household expenses. Therefore, $(\mathbf{N O H})$ the number of persons in the household is included. For some households a respondent's age might also affect willingness to pay for marginal increases in school quality than others (Miller 1996; Poterba 1997). Public services for the young may displace similar services for their age class or provide fewer tangible personal benefits. A dummy variable (OLDRET) for retirees is included.

\section{Local connections}

Local connections in the form of children attending public school, relatives who utilize public school, or employment in the school district may have an impact on demand for expenditures per student. For instance, some households choose not to send their children to the local public school. Households that would not choose to send their children to public school should be willing to pay less for improvements than other households. Rubinfeld et al. (1982) found a significant negative effect of a child not in public school on demand for expenditures for student. NOWAY represents this factor. Previous studies (Rubinfeld 1977; Lankford 1985) have shown that household employment in the school district affects demand for local schooling. Those households with members or immediate family employed in the school district (indicated by EMPDIST in the models) should desire greater expenditures made in the district than other households. By similar logic, one might expect households with no employment or familial connections (NOCON) to students in public schools to exhibit less demand for improvements in public school quality than other households.

\section{Expectations of success}

Respondents' feelings about how schoolwide improvements in achievement scores would affect their children may also affect willingness to pay. An improvement in schoolwide achievement scores does not mean that every child's learning would improve by the same amount. Respondents who believe that their child's learning will improve by more than $10 \%$ when school wide achievement scores increase by approximately $10 \%$ should be willing to pay more than other respondents for a designated increase in schoolwide scores. No prior studies have included such a variable such as $\boldsymbol{A F F}$.

\subsection{Empirical results}

\subsection{Willingness to pay estimates}

Table 5.1 presents a histogram of respondents' stated willingness to pay for a ten point improvement in their local school's achievement scores. 74.74\% of Hyndman and 60 percent of Bedford respondents exhibited a positive willingness to pay for a guaranteed improvement. Approximately twenty-five percent of all 
respondents in both areas were willing to pay at least $\$ 300$ per year for the guaranteed improvement and the mean bid. The mean bid for Hyndman was $\$ 264$ and Bedford is $\$ 240 .^{2}$ Since the Hyndman area lags behind Bedford area in school achievement, these results suggest that respondents exhibit a greater willingness to pay for marginal improvements in school quality if the starting point quality of school is lower. This result is consistent with marginal utility theory.

If one assumes that the population possesses the same characteristics as the respondents, it is possible to project population willingness to pay given the sample mean bids. Given the sample mean bids for Hyndman and Bedford, $\$ 290,795$ and $\$ 1,297,848$ would be available for programs to increase relative schoolwide achievement scores. The former represents approximately $22.2 \%$ of the current Hyndman and $24.9 \%$ of the Bedford educational budgets.

\subsection{Probit Analysis of zero bids}

To determine factors that influenced the probability that a respondent bid zero for improvements in public school quality, some underlying index indicating propensity to state a positive bid for increases in public school quality is assumed. This provided the basis for a probit analysis of household willingness to pay for marginal improvements in public school quality. The dependent variable for this analysis is one if the household stated a positive bid and zero if the respondent stated a zero bid. Predicted left hand side values can be interpreted as the predicted probability that an individual states a positive bid for increases in school quality. Any variable that has a significant negative impact on this probability can be seen as increasing the probability that a household bid is zero.

Econometric analysis with a binary dependent variable requires a larger amount of data than a continuous dependent variable. Therefore data from Bedford and Hyndman were combined for the probit analysis. A dummy variable which equaled one if the respondent was from the Hyndman area (HYND) was included in this analysis to account for differences in the Hyndman and Bedford areas. The results of this probit analysis are reported in Table 5.2. ${ }^{3}$

As expected, income (INCTEN) has a significant positive impact on the probability that a respondent submits a positive bid fro an increase in public school quality. That is, lower income households are more likely to bid zero for improved school quality. The sign of SWSEC indicates that perceived increased security of the household's primary income also increases the probability that respondents state a positive willingness to pay for improved school quality. The NOCONN variable is also negative and significant. This indicates that households with no current connection to the local public school are more likely to bid zero than other households. GRANDPUB is statistically significant but has an unexpected negative sign. This variable may be capturing an age effect not detected in the age 65 or older variable.

The $\boldsymbol{H Y N D}$ coefficient is positive and significant. This indicates that individuals from Hyndman are more likely to state a positive bid for improved school quality than those individuals from the Bedford area. These results are consistent with the a priori expectation that bids in Hyndman should be higher than bids in Bedford because Hyndman's public school grades 6-12 are currently lower quality than Bedford's public school grades 6-12. This provides some evidence that respondents exhibit diminishing marginal utility with respect to marginal increases in public school quality. If the initial quality difference in the schools was larger, the estimated coefficient on this variable would probably be more significant.

The remaining variables in the analysis are not significant. The most surprising of these are the variables indicating the number of children in school (GR6UD and GRK5). Thus, there is not support for the assumption that a household which currently has children in the local school system is more likely to state a positive bid for improved local school quality in the form of improved schoolwide achievement scores. The estimated parameters of $\boldsymbol{O C C W}$ and HIGHED are positive but not statistically significant. The simulated parameters of NOWAY and OLDRET are negative as expected but not statistically significant. The estimated parameters of EMPDIST and $\mathbf{N O H}$ have the wrong sign but are statistically insignificant. 


\subsection{Tobit Analysis of willingness to pay for increased public school quality}

Approximately $33 \%$ of all respondents did not make a positive bid for a guaranteed improvement in public school quality. Some percentage of these respondents would have probably requested a refund of some portion of their current household payment toward public education. However, this option was not presented to respondents. Therefore information on the dependent variable in this study is censored. Ordinary least squares estimation in this case leads to biased and inconsistent estimates of the coefficients. The Tobit model was specifically designed to handle the problem of a censored dependent variable. Therefore, the statistical analysis in this section utilizes the Tobit model estimated using maximum likelihood estimation.

Table 5.3 lists the results of the maximum likelihood Tobit analysis for Hyndman and Bedford. ${ }^{4}$ The estimated coefficient of household income (INCTEN) is positive and significant in Bedford and Hyndman. ${ }^{5}$ The estimated coefficient of income squared (INCTEN2)is negative and significant in Hyndman but is not significant in the Bedford model. Since it is reasonable to assume that willingness to pay for improvements in public education increases at a decreasing rate with respect to income, the relatively low significance level of income squared may be explained by an inflated standard error due to collinearity between INCTEN and INCTEN2.

Two variables in this study represent the effect of children currently enrolled in the local public school. The estimated parameter of GR6UD was positive as expected in the Hyndman model. This indicates that households which currently have children in grades six through twelve were willing to pay more than those who do not from an improvement in those grades. There is a direct user benefit to improved public school quality. However, the estimated parameter of this variable is not significant in the Bedford model. Bergstrom et al. (1982) attempted a similar breakdown in children by age but did not find the equivalent of GR6UD to be significant. However, Lankford (1985), Rubinfeld (1977), and Akin and Lea (1982) all found significant direct benefits for households with children in public school or households with children under the age of eighteen.

The estimated coefficient of GRK5D is not significant in either model and had an unanticipated negative sign. This indicates that households with children currently in grades $\mathrm{K}$ through five are not willing to pay more than other households for improvements in the quality of grades six through twelve. This may be due to the high level of expenditure in households with small children in conjunction with the fact that improvements in grades six through twelve offer no immediate benefits to children in grades $k$ through five.

$\boldsymbol{A F F}$ was intended to capture the differing effects schoolwide improvements would have on individual children. Households with children who are currently in public school grades six through twelve or are anticipated to attend public school grades six through twelve in the future were included in this variable. Even if the household's children are currently not in grades six through twelve the anticipated future benefit to the household should be greater if they believe their children's learning would improve by more than the schoolwide improvement in achievement scores. The coefficient of this variable is positive and significant. Its significance could have major implications for local public schools. If households with children whose learning is perceived to be more affected by educational improvement are willing to pay more than others for improvement, then these households may be more likely to send their children to other educational institutions. This may indicate that the best and brightest students are the ones most likely to be sent elsewhere if improvement in the local public school does not occur.

NOCONN measures connections to the local public school. The estimated parameter of this variable is negative and significant in Bedford and negative but insignificant for Hyndman. The lack of significance in Hyndman may be due to the size of the area. The population of Hyndman is much smaller than the population of the Bedford area. Perhaps in small areas even individuals with no connection to the local public school feel some financial responsibility that individuals from a larger area do not. Therefore in areas with a greater population this variable may become more significantly negative.

EMPDIST is positive and significant in Hyndman but is not significant in Bedford. Apparently school employees have a greater incentive to demand increased expenditure than they do increased school quality as measured by improved achievement scores. There are two possible explanations for this occurrence. School employees may have a greater lack of confidence in achievement scores to reflect real quality 
improvement than the remainder of the population, or school employees may be motivated more by selfinterest to demand increased expenditures than increased quality.

GRANDPUB is significant in Bedford and has an unexpected sign in both models. Perhaps households with grandchildren in the local public school are attempting to save money for retirement in the period soon after the exodus of their children from their immediate care. This is one plausible explanation for the negative sign on this variable in most of the models in this study.

The remainder of the variables listed in table 5.3 have estimated parameters which are not significant.

\subsection{Summary and Conclusions}

This paper examines a household willingness to pay for marginal improvements in public school quality. The results of this analysis indicate that the majority of respondents do value improved public school quality. Approximately two thirds of all respondents stated a positive willingness to pay for the first guaranteed improvement in public school quality. A probit analysis of zero bidders revealed that households with lower incomes, somewhat insecure in their major income source, no current connection in the local public school, and located in areas with better performing schools were more likely to bid zero than other households. A Tobit model of willingness to pay for increased school quality found that willingness to pay varied directly with income in Hyndman and Bedford. In Hyndman households with children currently in the grades affected by an improvement will pay more for improvements in public school quality. This indicates that there is a significant user or direct benefit from improved public school quality. However, this variable was not found to be significant in the Bedford model. This is probably due to the inclusion of another variable designed to determine how the presence of a child who has an above average potential for improved learning would affect household willingness to pay for improved public school quality. This variable consistently had a significant positive impact on household willingness to pay for improved public school quality.

These findings have certain policy implications. First, results indicate that individuals are willing to pay for certain improvements, even, we might add without a guarantee in school quality. This suggests that additional funds might be raised for well-structured public school programs that have a defined improvement goal.

Second, in recent times the United States has been confronted with a stagnant economy in which some regions have fallen into recession. During a recession household income falls and becomes less secure. These results indicate that any region in the midst of recession will find more households unwilling to pay for public school improvement. Therefore a school administration may be less likely to find willing providers of additional money for public school improvement during a recession.

Third, the analysis of zero bidders indicated that households with no current connection to the public school are more likely to bid zero than others. Households that move often are less likely to have current connections to the local public school. It seems reasonable to assume that areas where the residents are more transient will find more households unwilling to pay for improvements in local public school quality. School districts where a large proportion of the local population has no connection to the local public school may be unable to increase spending to increase quality.

Fourth, since Tobit model results suggest that higher income households and households with children currently in public school are more willing to pay for school improvement, it might be suggested that one way to raise dollars necessary for school improvement would be an income tax combined with a user fee based on children currently in public school.

Fifth, the significant positive effect of the presence of a child whose potential for improved learning is perceived to be above average could be potentially foreboding to public schools in the absence of school improvement, these children would be more likely than others to be sent to a private educational institution. Some areas are currently considering allowing public school choice with no provision for public transportation to other schools. These results indicate that households with a child perceived to have an above average potential for learning improvement are more likely to be willing to pay the increased expense or bear the opportunity costs of transporting their children to other schools. Lower quality public schools may lose their best students under these conditions. 


\section{Endnotes}

${ }_{1}^{1}$ Tiebout (1956) suggested that people are likely to locate in areas that provide the level of local public goods that they desire. For this reason, households located in an area with a higher level of public school expenditure per student may desire a higher level of public school expenditure per student, ceteris paribus. Failure to consider the fact that households may gravitate toward areas which provide their desired level of public school expenditure could result in an erroneous conclusion about the efficiency of local public school spending.

${ }^{2}$ Respondents were also asked their willingness to pay for a program or policy designed to achieve the same improvement when the results are not guarantees. Here, $60 \%$ of Hyndman and $57 \%$ of Bedford respondents were willing to pay for such a program. However, the percent of respondents willing to pay dropped approximately $10.5 \%$ and $15,8 \%$ respectively from the previous certain scenario.

${ }^{3}$ Belsley, Kuh and Welsch (1980) diagnostics indicate that collinearity was not present in the probit analysis. Furthermore, a multiplicative test revealed no heteroskedasticity problems.

${ }^{4}$ Regression diagnostics indicate that collinearity is a problem only between income and income squared. Therefore the significance of the simulated coefficients may be artificially low because of variance inflation. Also, influence diagnostics developed by Belsley, Kuh, and Welsch (1980) indicated that the linear model was not driven by any unusual observations.

${ }^{5}$ The estimated income elasticity of willingness to pay for a marginal increase in public school quality in Bedford given these results is 1.45. The parallel income elasticity in Hyndman is 1.39. These are somewhat higher than the income elasticities of demand for expenditures per student determined in previous studies. Using micro data Bergstrom et al. (1982) determined income elasticities for increased expenditure per student ranging from .38 to .83 using four different models. Also using micro data Lankford (1985) estimated an average income elasticity of demand for increased expenditures per student to be equal to 4 . Bergstrom's (1982) and Lankford's (1985) income elasticities are based on expenditures per student. Increased expenditures per student do not constitute a guaranteed public school quality increase. Since the dependent variable in this analysis represents maximum household willingness to pay for a guaranteed quality increase, it seems reasonable to expect that the income elasticity calculated from this model would be higher than income elasticities calculated based on increased expenditure per student. 


\section{References}

Akin, $\mathrm{J}$ and M Lea (1982) Microdata estimation of school expenditure levels: An alternative to the median voter approach. Public Choice 38: 113-128.

Akin, J and D. Youngday (1976) The efficiency of local school finance. Review of Economics and Statistics. 58: 255-58.

Barlow, R (1970) Efficiency aspects of local school finance. Journal of Political Economy 78: 1028-1040.

Belsley, D, E Kuh, and R Welsch (1980) Regression diagnostics: Identifying influential data and sources of collinearity. New York: John Wiley and Sons.

Bergstrom, T, D Rubinfeld, and P Shapiro (1982) Micro-based estimates of demand functions for local public education. Journal of Public Economics 35: 289-307.

Bishop, R, P Champ, and D Mullarkey (1995) Contingent valuation. In (Ed. D Bromley) The Handbook of Environmental Economics. Oxford: Basil Blackwell Ltd.

Carson, R T (2000) Contingent valuation: A user's guide. Environmental Science and Technology 34, 8: 1413-1418.

Carson, R T, J L Wright, N J Carson, A Alberini, and N E Flores (1995) A bibliography of contingent valuation studies and papers. La Jolla, CA: NRDA, Inc.

Chambers, C, P Chambers, and J Whitehead (1996) Contingent valuation of a quasi-public goods: Validity, reliability, and application to a valuing a historic site. East Carolina University, Department of Economics. Working Paper 9614.

Cornes, R and T Sandler (1986) The theory of externalities, public goods, and club goods. New York: Cambridge University Press.

Hanley, Nick and Clive L. Spash (1993) Cost-benefit analysis and the environment. Brookfield, VT: Edward Elgar Publishing Company.

Hanushek, E (1986) The economics of schooling. Journal of Economic Literature. 24: 1141-1177.

Heckman, James J (2000) Policies to foster human capital. Research in Economics 54: 3-56.

Kawagoe, $\mathrm{K}$ and N Fukunaga (2001) Identifying the value of public services by the contingent valuation method (CVM). Nomura Research Institute. NRI Papers No 39.

Lankford, R. H. (1985) Preferences of citizens for public expenditures on elementary and secondary education. Journal of Econometrics 27: 1-20.

Lankford, R. H. (1986) Efficiency and equity in the provision of public education. Review of Economics and Statistics 67: 70-80.

Lovell, M (1978) Spending for education: The exercise of public choice. Review of Economics and Statistics 60: 478-495.

Miller, Cynthia (1996) Demographics and spending for public education: a test of interest group influence. Economics of Education Review. 15, 2: 175-185.

Mitchell, R. and R. Carson (1989) Using Surveys to Value Public Goods, The Contingent Valuation Method. Resources for the Future. Washington, DC. 
Poterba, J. M. (1997) Demographic structure and the political economy of public education. Journal of Policy Analysis and Management. 16: 48-66.

Rubinfield, D. (1977) Voting in a local school election: A micro analysis. Review of Economics and Statistics. 59: 30-42.

Stair, Anthony (1993) Household willingness to pay for improvements in public school quality. Dissertation, Morgantown, West Virginia University.

Thurston, Hale (2000) Non-market valuation on the Internet. Book chapter under review by editor, August 2000.

Tiebout, C M (1956) A pure theory of local expenditures. Journal of Political Economy 64: 416-424.

Tietenberg, T (2000) Environmental and natural resource economics ( $5^{\text {th }}$ edition). Boston: Addison-Wesley.

Turner, R. Kerry (1999) The place of economic values in environmental valuation. In (Eds. I Bateman, K Willis) Valuing Environmental Preferences: Theory and Practice of the Contingent Valuation Method in the US, EU, and Developing Countries. New York: Oxford University Press.

Water Resources Council. 1979. Procedures for evaluation of national economic development (NED): Benefits and costs in water resources planning (Level C), final rule. Federal Register 44(242) December 14 pp. 72892-977. 
Table 4.1 Variable Descriptions

\begin{tabular}{|c|c|c|c|}
\hline$\underline{\text { Variable }}$ & Description & Definition & Expected Sign \\
\hline$\overline{A F F}$ & $\begin{array}{l}\text { Respondent feelings } \\
\text { about the effect of } \\
\text { improved achievement } \\
\text { scores on their child's } \\
\text { learning. }\end{array}$ & $\begin{array}{l}\text { Respondent feelings } \\
\text { about the effect of } \\
\text { improved } \\
\text { achievement. }\end{array}$ & + \\
\hline EMPDIST & $\begin{array}{l}\text { Employed in the } \\
\text { school district }\end{array}$ & $\begin{array}{l}\text { If any member of the } \\
\text { household or } \\
\text { immediate family is } \\
\text { currently employed in } \\
\text { the school district }=1,0 \\
\text { otherwise. }\end{array}$ & + \\
\hline GRANDPUB & $\begin{array}{l}\text { Grandchildren } \\
\text { currently in public } \\
\text { school }\end{array}$ & $\begin{array}{l}\text { If the household } \\
\text { currently ahs } \\
\text { grandchildren in local } \\
\text { public school=1, } 0 \\
\text { otherwise. }\end{array}$ & + \\
\hline GR6UD & $\begin{array}{l}\text { Number of children } \\
\text { currently enrolled in } \\
\text { grades } 6 \text { through } 12\end{array}$ & $\begin{array}{l}\text { If household currently } \\
\text { has children enrolled } \\
\text { in grades } 6-12=1 \text {, } \\
\text { otherwise } 0 \text {. }\end{array}$ & + \\
\hline GRK5UD & $\begin{array}{l}\text { Number of children } \\
\text { enrolled in grades k-5 }\end{array}$ & $\begin{array}{l}\text { If household currently } \\
\text { has children enrolled } \\
\text { in grades } k-5=1,0 \\
\text { otherwise. }\end{array}$ & + \\
\hline HIGHED & $\begin{array}{l}\text { Highest education } \\
\text { level completed by } \\
\text { man or woman }\end{array}$ & $\begin{array}{l}\text { Year of education } \\
\text { completed (i.e., } \\
12=\text { high school } \\
\text { graduate) }\end{array}$ & + \\
\hline INCTEN & Household Income & $\begin{array}{l}\text { Income for each } \\
\text { respondent entered as } \\
\text { the average of } \\
\text { respondents stated } \\
\text { income range. }\end{array}$ & + \\
\hline INCTEN2 & $\begin{array}{l}\text { Household Income } \\
\text { Squared }\end{array}$ & $\begin{array}{l}\text { Square of household } \\
\text { income }\end{array}$ & - \\
\hline NOCONN & $\begin{array}{l}\text { Household has no } \\
\text { connection to anyone } \\
\text { currently in the public } \\
\text { school }\end{array}$ & $\begin{array}{l}\text { If the household } \\
\text { currently has no } \\
\text { connection to anyone } \\
\text { in the public school=1, } \\
0 \text { otherwise }\end{array}$ & - \\
\hline
\end{tabular}




\begin{tabular}{|l|l|l|l|}
\hline NOH & $\begin{array}{l}\text { Number of persons } \\
\text { currently in the } \\
\text { household }\end{array}$ & $\begin{array}{l}\text { This variable is not } \\
\text { entered as a dummy } \\
\text { variable. }\end{array}$ & - \\
\hline NOWAY & $\begin{array}{l}\text { Household having } \\
\text { children of the } \\
\text { appropriate age who } \\
\text { currently do not attend } \\
\text { the local public school }\end{array}$ & $\begin{array}{l}\text { If household has } \\
\text { children of the } \\
\text { appropriate age who } \\
\text { do not currently attend } \\
\text { local public school=1, } \\
\text { 0 otherwise }\end{array}$ & - \\
\hline OCCW & $\begin{array}{l}\text { Occupation of the } \\
\text { individuals that } \\
\text { constitute the } \\
\text { household }\end{array}$ & $\begin{array}{l}\text { If either person within } \\
\text { household is a white } \\
\text { collar worker=1, 0 } \\
\text { otherwise }\end{array}$ & + \\
\hline OLDRET & $\begin{array}{l}\text { Age of respondent } \\
\text { If respondent's age is } \\
\text { greater than 64=1, 0 } \\
\text { otherwise }\end{array}$ & - \\
\hline SWSEC & $\begin{array}{l}\text { Primary income earner } \\
\text { perceived income } \\
\text { security }\end{array}$ & $\begin{array}{l}\text { If the income of the } \\
\text { primary income earner } \\
\text { is perceived as } \\
\text { somewhat or very } \\
\text { secure=1, 0 otherwise }\end{array}$ & + \\
\hline
\end{tabular}


Table 5.1 Histogram of the final bid for an improvement in schoolwide achievement scores.

\begin{tabular}{|c|c|c|c|c|c|}
\hline $\begin{array}{l}\text { Range } \\
\text { Frequency }\end{array}$ & \multicolumn{2}{|c|}{$\begin{array}{l}\text { Hyndman Frequency } \\
\text { Bedford Cumulative Frequency }\end{array}$} & \multicolumn{2}{|c|}{ Hyndman Cumulative Frequency } & Bedford \\
\hline 0 & $24(.2526)$ & $24(.2526)$ & $38(.4000)$ & $38(.4000)$ & \\
\hline$\$ 1-99$ & $18(.1895)$ & $42(.4421)$ & $11(.1158)$ & $49(.5158)$ & \\
\hline$\$ 100-199$ & $19(.2000)$ & $61(.6421)$ & $14(.1474)$ & $63(.6632)$ & \\
\hline$\$ 200-299$ & $10(.1053)$ & $71(.7474)$ & $8(.0842)$ & $71(.7474)$ & \\
\hline$\$ 300-399$ & $4(.0421)$ & 75 (.7895) & $6(.0632)$ & 77 (.8105) & \\
\hline$\$ 400-499$ & $9(.0947)$ & $84(.8842)$ & $2(.0211)$ & $79(.8316)$ & \\
\hline$\$ 500-999$ & $4(.0421)$ & $88(.9263)$ & $13(.1368)$ & $92(.9684)$ & \\
\hline$\$ 1000-1999$ & $6(.0632)$ & 94 (.9895) & $2(.0211)$ & $94(.9895)$ & \\
\hline$\$ 2000-2999$ & $1(.0105)$ & $95(1.000)$ & $1(.0105)$ & $95(1.000)$ & \\
\hline
\end{tabular}

Table 5.2 Results of probit analysis of zero bids

\begin{tabular}{|c|c|c|c|}
\hline VariableCoefficient & t-ratio & & \\
\hline Constant & -1.465 & $-1.846^{*}$ & \\
\hline INCTEN & .465 & $3.487^{* * *}$ & 2.263 \\
\hline GR6UD & -.019 & -.044 & .168 \\
\hline GRK5D & -.437 & -.811 & .089 \\
\hline$A F F$ & 3.845 & .085 & .068 \\
\hline HIGHED & .047 & .0810 & 12.432 \\
\hline GRANDPUB & -.763 & $-2.368^{\star *}$ & .232 \\
\hline$O C C W$ & .157 & .490 & .337 \\
\hline $\mathrm{NOH}$ & .072 & .570 & 2.526 \\
\hline EMPDIST & -.177 & -.364 & .089 \\
\hline NOCONN & -.963 & $-2.915^{\star * *}$ & .263 \\
\hline SWSEC & .729 & $2.359^{* *}$ & .832 \\
\hline NOWAY & -1.065 & -1.566 & .042 \\
\hline OLDRET & -.124 & -.434 & .300 \\
\hline HYND & .492 & $1.987^{*}$ & .500 \\
\hline Log-likelihood & -77.121 & & \\
\hline Chi-squared & 85.743 & & \\
\hline Significance Level & .100000 E-06 & & \\
\hline
\end{tabular}


Table 5.2 Tobit model maximum likelihood results for Bedford and Hyndman

Bedford

\begin{tabular}{lrrrrrr} 
Variable & Coefficient & \multicolumn{1}{c}{ t-ratio } & Mean of $x$ & \multicolumn{1}{c}{ Coefficient } & t-ratio & Mean of $x$ \\
Constant & -453.890 & $-1.898^{*}$ & & -725.520 & $-2.333^{* *}$ & \\
INCTEN & 184.160 & $3.483^{\star * *}$ & 2.30 & 280.090 & $2.777^{\star * *}$ & 2.217 \\
INCTEN2 & -7.025 & -1.386 & 8.301 & -25.744 & $-1.869^{*}$ & 6.824 \\
GR6UD & 78.439 & .647 & .158 & 259.500 & $2.169^{\star *}$ & .179 \\
GRK5D & -131.520 & -1.027 & .084 & -255.750 & -1.625 & .095 \\
AFF & 761.540 & $4.913^{\star * *}$ & .053 & 322.370 & $2.275^{\star *}$ & .084 \\
HIGHED & 17.863 & .943 & 12.821 & 12.082 & .547 & 12.042 \\
GRANDPUB & -242.080 & $-2.270^{* *}$ & .221 & -113.830 & -1.004 & .242 \\
OCCW & -51.201 & -.572 & .389 & 130.460 & 1.238 & .284 \\
NOH & -13.791 & -.393 & 2.484 & 28.459 & .581 & 2.568 \\
EMPDIST & 72.684 & .545 & .084 & 234.070 & $1.689^{*}$ & .095 \\
NOCONN & -173.680 & $-1.802^{*}$ & .358 & -141.930 & -.997 & .168 \\
SWSEC & 145.390 & 1.306 & .842 & 194.870 & 1.499 & .821 \\
NOWAY & -267.890 & -1.628 & .063 & -70.651 & -.240 & .021 \\
OLDRET & 19.686 & .226 & .305 & 23.780 & .200 & .295
\end{tabular}

\section{Hyndman}

Log-likelihood

$$
-426.760
$$

* Statistically significant at .10 level

** Statistically significant at .05 level

*** Statistically significant at .01 level 